DOI: https://doi.org/10.34069/AI/2021.47.11.20

How to Cite:

Shelestova, A., Solianyk, A., Bachynska , N., Novalska, T., \& Kobieliev, O. (2021). Libraries of pedagogical institutions of higher education on social media. Amazonia Investiga, 10(47), 197-206. https://doi.org/10.34069/AI/2021.47.11.20

\title{
Libraries of pedagogical institutions of higher education on social media
}

\section{Бібліотеки педагогічних закладів вищої освіти у соціальних медіа}

Received: October 2, 2021

Accepted: November 30, 2021

\author{
Written by: \\ Anna Shelestova ${ }^{84}$ \\ https://orcid.org/0000-0003-4866-1767 \\ Alla Solianyk ${ }^{85}$ \\ https://orcid.org/0000-0002-7167-6695 \\ Nadiia Bachynska ${ }^{86}$ \\ https://orcid.org/0000-0003-3912-7108 \\ Tetyana Novalska ${ }^{87}$ \\ https://orcid.org/0000-0003-3093-3998 \\ Oleksii Kobieliev $^{88}$ \\ https://orcid.org/0000-0002-6322-0735
}

\begin{abstract}
The article aims to explore nowadays promoting conditions of libraries of pedagogical institutions of higher education on social media and define effectiveness criteria of this process. Content analysis of official accounts of 19 libraries of pedagogical institutions of higher education in Ukraine is provided. Based on the results of content analysis the authors explore the current state of representing their information products and services on social networks, specify the factors that contribute to the effectiveness of promoting library services among users. The authors indicate the following factors which influence the followers number: correct use of hashtags, authenticity and frequency of content updating, maximum content synchronization of the library profiles on various social networks for uniform information and involvement of their target audiences; insight and successful use of functionality of various social networks by librarians.
\end{abstract}

\begin{abstract}
Анотація
Метою статті $\epsilon$ вивчення сучасного стану просування бібліотек педагогічних закладів вищої освіти в популярних соціальних мережах та визначення критеріїв ефективності цього процесу. Здійснено контент-аналіз офіційних акаунтів 19 наукових бібліотек провідних педагогічних закладів вищої освіти України. Узагальнення результатів контент-аналізу дозволило встановити сучасний стан репрезентації їх інформаційних продуктів та послуг в соціальних мережах, визначити чинники, що сприяють підвищенню ефективності просування бібліотечних сервісів серед користувачів. Серед чинників, що впливають на кількість підписників бібліотечних акаунтів, зазначено коректне застосування хештегів, оригінальність та частота оновлення контенту, максимальна синхронізація контенту сторінок бібліотек у різних соціальних мережах для рівномірного інформування та залучення їх цільових аудиторій; розуміння та вдале застосування
\end{abstract}

\footnotetext{
${ }^{84} \mathrm{PhD}$ in Social Communication Sciences, Associate Professor at the Information Technologies Chair, Kharkiv State Academy of Culture, Kharkiv, Ukraine.

${ }^{85}$ Doctor of Pedagogical Sciences, Professor, Head of the Social Communications, Museum and Tourism Activities Department, Kharkiv State Academy of Culture, Kharkiv, Ukraine.

${ }^{86} \mathrm{PhD}$ in Pedagogical Sciences, Associate Professor, Head of the Information Technologies Chair, Kyiv National University of Culture and Arts, Kyiv, Ukraine.

${ }^{87}$ Doctor of Historical Sciences, Professor, Professor at the Information Technologies Chair, Kyiv National University of Culture and Arts, Kyiv, Ukraine.

${ }^{88}$ Doctor of Social Communication Science, Associate Professor, Professor at the Information, Librarian, Archive Chair, Kharkiv State Academy of Culture, Kharkiv, Ukraine.
} 
Keywords: libraries, social media (social networks), effectiveness criteria, pedagogical institutions of higher education, Ukraine.

\section{Introduction}

An important condition for the sustainable development of Ukraine and its successful integration into the European educational space is to train a new generation of teachers who can significantly increase the level of education of citizens, to form a system of competencies in them that will ensure their competitiveness in a digitalized society dominated by 4.0 technologies. The draft "Strategies for the (Ministry of Education and Science of Ukraine, 2020) presented by the Ministry of Education and Science of Ukraine sets out a number of priorities on seven strategic goals of determining updating educational practices. Libraries of pedagogical institutions of higher education (HEI) of Ukraine should join the implementation of almost every task as a key link in the system of scientific methodological and information support of the development of the educational sector. In the context of digital economics and education, the task of forming a proactive system of network services of libraries of pedagogical HEI, providing the users with round-the-clock remote access to online information resources and services, as well as through the accounts on popular social networks. An important competence of a modern librarian is not only digital - the ability to professionally handle digital technologies, resources and services, but also pedagogical - the ability to teach the users to apply digital library information products and services as a condition for effective mastery of professional skills.

The vast majority of users of research libraries of pedagogical HEI are students focused on communication through social networking websites. The undisputed leaders among youth are such social networks as Instagram, Telegram, Tik-Tok. Therefore, libraries should take into account which social networks their target audience prefers, and systematically build effective digital interaction with their users. The current state and development trends of communication of libraries with the users on social media have been established on the basis of content analysis of accounts of research libraries of 19 pedagogical HEI of Ukraine of IIIIV levels of accreditation of the state and municipal forms of ownership. бібліотекарями алгоритмів роботи різних соціальних мереж.

Ключові слова: бібліотеки, соціальні мережі, критерії ефективності, педагогічні заклади вищої освіти, Україна.

The object of research is the content of accounts of libraries of pedagogical HEI of Ukraine on social media.

The subject of the research is the level of efficiency of promoting information products and services of libraries of pedagogical HEI of Ukraine on social media.

The purpose of the study is to develop a strategy for effective promoting information products and library services of pedagogical HEI of Ukraine on social media.

\section{Literature Review}

Analyzing the state of development of this issue, it should be emphasized that Ukrainian scholars pay special attention to the integration of libraries into the Internet. Thus, O. Marina (2017) in her doctoral monograph "Library in the Digital Space" emphasizes the need for modern libraries to find tools and mechanisms for entering the Internet space in order to build interactive communication with the user. Back in 2012, the researcher substantiates the urgent need to establish interaction "library - user" on social media (Marina, 2012). No less relevant is the monograph by V. Bondarenko (2016)] that is concerned with the characteristic features of the current state and prospects for the development of library Internet services, but the author does not pay enough attention to the issues of establishing communication with library users on social networks.

General theoretical and technical and technological principles of modeling the marketing activities of modern institutions on Internet communities are productively developed in the works of V. Horoviy (2010), O. Peleshchyshyn, K. Molodetska, A. Solianyk, R. Kravets (2019). Regarding the libraries of Ukraine, the issues of developing the general strategies for promoting their products and services on social media have been objectively considered by H. Bulakhova (2013), I. Davydova, O. Marina, A. Solianyk, Y. Syerov (2019). T. Hranchak (2016) reveals the untapped opportunities of libraries concerning the social 


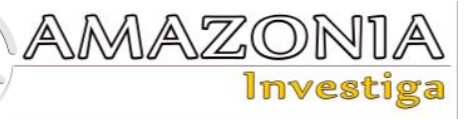

networks as a marketing tool for promoting information products and services to users in her works (Hranchak, 2019).

In the context of advertising strategies for the implementation of the results of library production H. Bulakhova (2017), V. Strunhar (2016) and M. Samsonov (2012) analyze the possibilities of social networks. According to the results of the analysis of the content of library profiles on the social network Facebook $\mathrm{H}$. Bulakhova (2016) characterizes their main functions: representative capacity, information, communication, navigation, remedial, studying the social structure of people (2016).

V. Strunhar $(2014,2017)$ substantiates the potential for improving the content of library accounts on social media, emphasizing the need to expand the topics and increase the intensity of publishing messages. E. Kulyk (2015) pays attention to the areas for improvement of the virtual space of libraries as an environment for education and self-education of youth and characterizes the profiles on popular social networks as a convenient and efficient, but insufficiently involved communication channel. N. Tarasenko (2017) remarks that "Ukrainian libraries most actively use Facebook to create their websites. However, according to a study of a number of Facebook websites of the largest national libraries, they do not have a single concept of initiation, significantly differ in interface, informative value, filling with content, search capabilities, which, accordingly, determine the different efficiency of web pages of libraries and significantly affect the level of a user's interest in these resources" (Tarasenko, 2017, p. 463). N. Pasmor and N. Frolova (2016) examine the management of library websites as an effective tool for their network positioning and communication policy.

A detailed description of the current state of network digital resources of Ukrainian educational libraries is given in the research of $\mathrm{A}$. Humenchuk, N. Michanyn, T. Novalska and O. Trach (2019). The researchers have conducted a thorough analysis of the content of the websites of the network of educational libraries, making it possible to determine the features of the thematic and type-specific composition of their full-text resources, to propose a strategy of corporate interaction aimed at consolidating the digital resources of pedagogical libraries of Ukraine. But, despite the large number of scientific papers on online tools for the representation of library products and services, the issue of developing interactive communication of educational libraries with the users by effective representation on social networks still requires thorough research, which has led to the relevance of this study.

\section{Methodology}

The authors used systematic approach to explore the network of libraries of pedagogical institutions of higher education in Ukraine. The most active libraries were defined, they have continuously updating official accounts on one or more popular social network. The libraries' account content was explored with content analysis. Statistic method helped to determine: the number of libraries' account on social media such as Facebook, Instagram, YouTube, Twitter; the percentage of accounts with high, middle and low frequency of content updating; the followers' number; likes' number etc. Ranking method helped to determine top 5 the most active libraries which promote their information resources and services on social media.

In 2019, V.O. Sukhomlynskyi State Scientific and Pedagogical Library of Ukraine conducted a study "Scientific and Methodological Principles of Development of Educational Libraries as an Important Component of the Educational Environment", which substantiates the importance of systemic transformations in the activities of libraries based on the use of information and communication technologies, which provides "adequate response of libraries to global changes in the society" (Dobko, \& Khemchian, 2019, p. 91). In this regard, improving the information content of library websites and increasing their level of presence on popular social networks is an important way to stimulate the internal market of production, use and consumption of digital library information products and services.

Libraries of institutions of higher education that train future teachers play a crucial role in forming a system of digital competences in them, in particular, through active involvement in using information products and services by library websites and social media accounts. In order to determine the effectiveness of this area of pedagogical libraries of HEI of Ukraine in early 2021, a study of the state of functioning of 19 library websites and accounts on popular social media among students was conducted, which enabled to establish the degree and quality of communication with the users, identify the trends and potential for its improvement. 
To achieve this goal it is necessary to solve the following tasks:

- Identify the institutions of higher education of Ukraine that provide pedagogical education;

- Determine the availability and effectiveness of the websites of libraries of pedagogical HEI of Ukraine;

- Establish the degree of presence of libraries of pedagogical HEI of Ukraine on social media by logging their official user accounts;

- Conduct the content analysis of library accounts of pedagogical HEI of Ukraine on social media; identify the potential for raising the efficiency of library activities on social networks.

The study is based on the methodologies of system, communication, comparative approaches, the method of statistical analysis and content analysis of sites and accounts on social media of 19 libraries of pedagogical HEI of
Ukraine, which made it possible to substantiate in a scientific manner the development prospects of the presence of libraries on social networks, offer the means to promote their information products and services among students.

\section{Results and Discussion}

All of the 19 libraries of pedagogical HEI of Ukraine under study have their own websites or web pages. The data collected under the statistical study are illustrated in Table 1. In percentage correlation $100 \%$ of research libraries of pedagogical HEI have their own websites, the content of which covers cultural and educational, scientific activities, and the functionality of the websites provides access of remote users to electronic catalogues, digital repositories, and virtual exhibitions, provides them with the opportunities to receive a variety of online information services. $84 \%$ of libraries have their own official web profiles on popular social media Facebook, Instagram, YouTube etc., especially among students.

Table 1.

The presence of libraries of pedagogical HEI on the Internet space (by Anna Shelestova)

\begin{tabular}{|c|c|c|c|}
\hline \# & Name of the Library & $\begin{array}{l}\text { Availability } \\
\text { of a website }\end{array}$ & $\begin{array}{l}\text { Availability of an official } \\
\text { library account on social } \\
\text { networks }\end{array}$ \\
\hline .1 & $\begin{array}{l}\text { Library of the Berdyansk State Pedagogical } \\
\text { University }\end{array}$ & + & $\begin{array}{l}\text { Facebook } \\
\text { Instagram }\end{array}$ \\
\hline .2 & $\begin{array}{l}\text { Library of Oleksandr Dovzhenko Hlukhiv } \\
\text { National Pedagogical University } \\
\text { Library of the State Higher Educational }\end{array}$ & + & $\begin{array}{l}\text { Facebook } \\
\text { YouTube } \\
\text { Facebook }\end{array}$ \\
\hline .3 & $\begin{array}{l}\text { Institution "Donbass State Pedagogical } \\
\text { University" }\end{array}$ & + & $\begin{array}{l}\text { YouTube } \\
\text { Instagram }\end{array}$ \\
\hline .4 & $\begin{array}{l}\text { Library of Drohobych Ivan Franko State } \\
\text { Pedagogical University }\end{array}$ & + & $\begin{array}{l}\text { Facebook } \\
\text { Instagram } \\
\text { YouTube }\end{array}$ \\
\hline .5 & $\begin{array}{l}\text { Library of Volodymyr Vynnychenko Central } \\
\text { Ukrainian State Pedagogical University }\end{array}$ & + & Facebook \\
\hline 6 & $\begin{array}{l}\text { Library of the Kryvyi Rih State Pedagogical } \\
\text { University }\end{array}$ & + & $\begin{array}{l}\text { Facebook } \\
\text { Instagram }\end{array}$ \\
\hline .7 & $\begin{array}{l}\text { Library of Bohdan Khmelnytsky Melitopol } \\
\text { State Pedagogical University }\end{array}$ & + & Facebook \\
\hline .8 & $\begin{array}{l}\text { Research Library of the National Pedagogical } \\
\text { Drahomanov University }\end{array}$ & + & $\begin{array}{l}\text { Facebook } \\
\text { Twitter } \\
\text { Instagram } \\
\text { YouTube }\end{array}$ \\
\hline .9 & $\begin{array}{l}\text { Library of Hryhorii Skovoroda University in } \\
\text { Pereiaslav }\end{array}$ & + & Facebook \\
\hline .10 & $\begin{array}{l}\text { Library of K. D. Ushinsky South Ukrainian } \\
\text { National Pedagogical University }\end{array}$ & + & $\begin{array}{l}\text { Facebook } \\
\text { Instagram } \\
\text { YouTube }\end{array}$ \\
\hline .11 & $\begin{array}{l}\text { Library of Poltava V.G. Korolenko National } \\
\text { Pedagogical University }\end{array}$ & + & Facebook \\
\hline
\end{tabular}


Research Library of the Sumy State

.12 Pedagogical University named after

A. Makarenko

.13 Research Library of Ternopil Volodymyr Hnatiuk National Pedagogical University

Research Library of the Ukrainian Engineering Pedagogics Academy

.15 Library of Pavlo Tychyna Uman State Pedagogical University

Library of the Municipal Establishment

.16 "Kharkiv Humanitarian-Pedagogical Academy" of the Kharkiv Regional Council

Research Library of H.S. Skovoroda Kharkiv National Pedagogical University

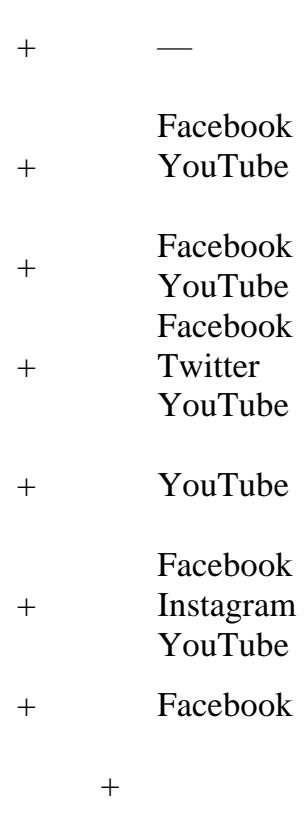

Figure 1 illustrates the ratio of libraries of pedagogical HEI of Ukraine, having presence on the Internet by their own websites, or web pages

$(100 \%)$ and their own official pages on social networks Facebook, Instagram, YouTube activities (84\% of libraries).
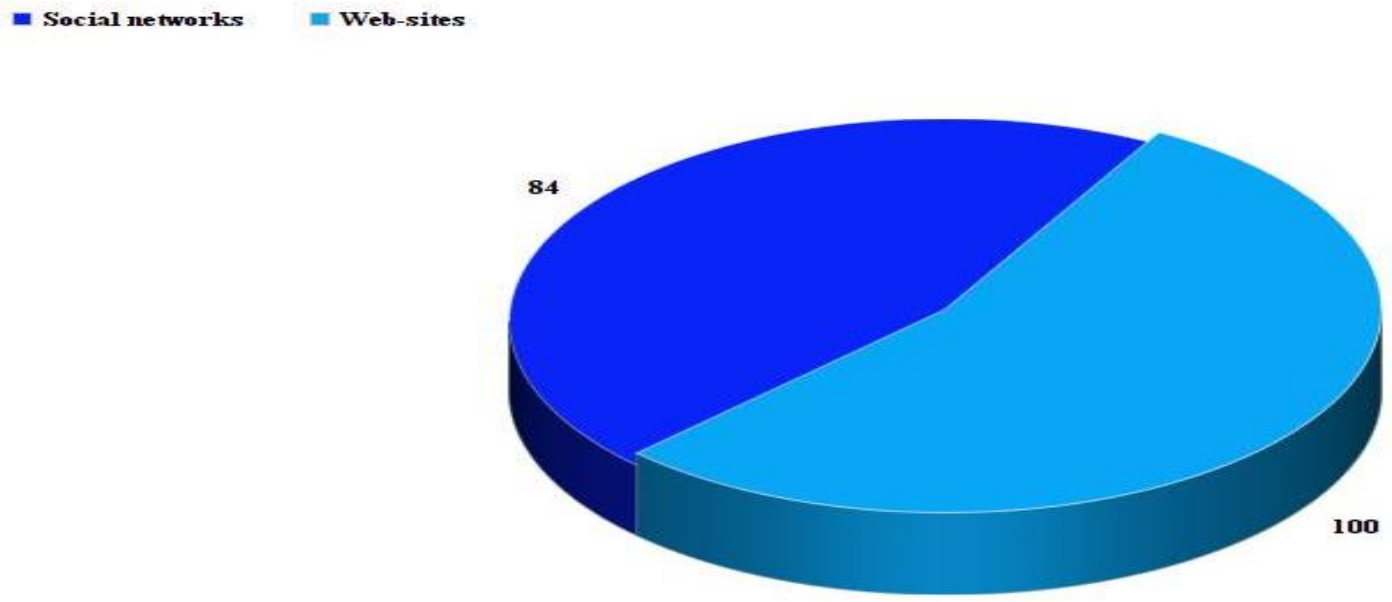

Figure 1. The presence of libraries of pedagogical HEI on the Internet (by Anna Shelestova)

Concerning the content of the websites of the libraries of pedagogical HEI, it should be emphasized that in general they have similar content: news, announcements, virtual exhibitions, electronic catalogues, repositories. According to Webometrics, among the 64 most popular Ukrainian repositories, the 5 best digital repositories of the libraries of pedagogical HEI of Ukraine were found. According to the capacity criteria of the digital repository, the ranking of these libraries has been as follows:
- 1 position - National Pedagogical Drahomanov University;

- 2 position - Ternopil Volodymyr Hnatiuk National Pedagogical University;

- 3 position — Poltava V.G. Korolenko National Pedagogical University ;

- 4 position - Ukrainian Engineering Pedagogics Academy;

- 5 position - Vinnytsia Mykhailo Kotsiubynskyi State Pedagogical University (NTB TNTU lleva el nombre de Ivan Pulyuy, 2021). 
According to the results of the analysis of the presence of research libraries of pedagogical HEI of Ukraine on social networks, it is established that most of them have their official websites on social media; their ratio is illustrated in Figure 2:
- 1 position - Facebook (84\%: 21\% - groups; $63 \%$ - pages);

- 2 position - YouTube $(53 \%)$;

- 3 position - Instagram (36\%);

- 4 position - Twitter $(11 \%)$.

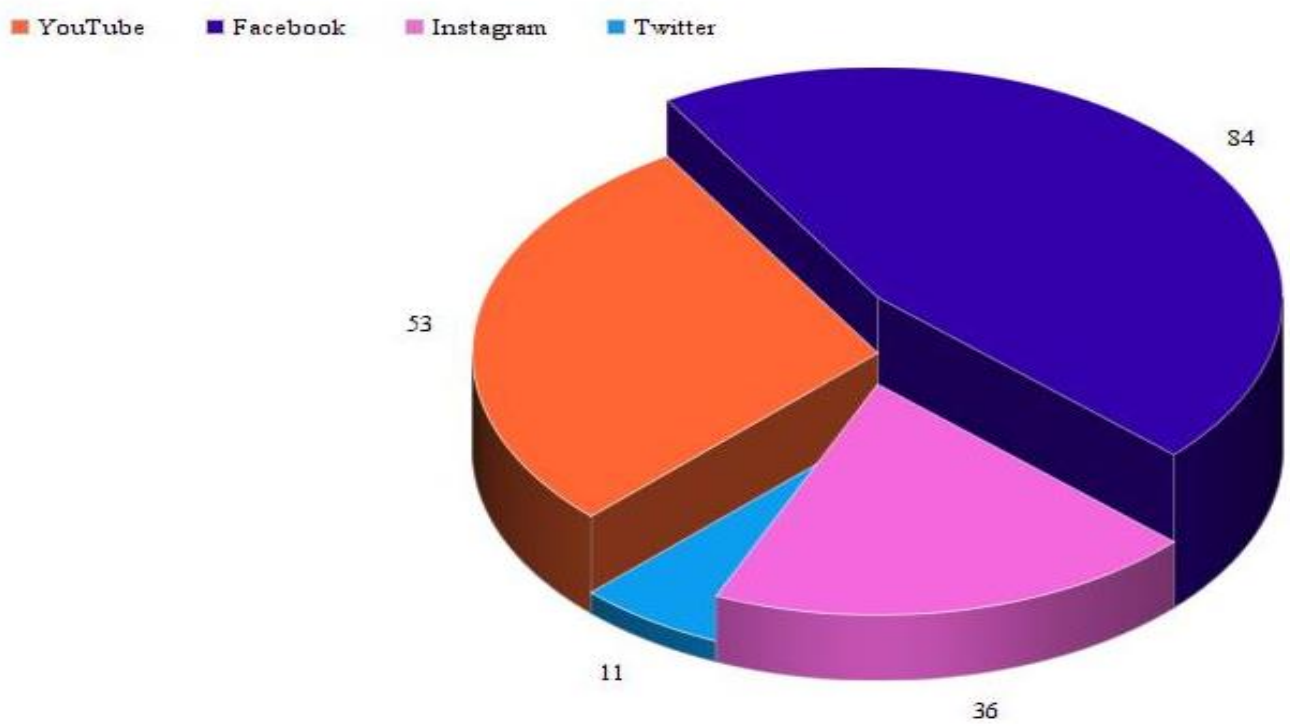

Figure 2. Comparative diagram of the popularity of social media among the libraries of pedagogical HEI (by Anna Shelestova)

According to the content analysis and the data update rate of library accounts on social networks, Facebook and Instagram pages are most actively filled and updated. But a significant drawback was that the content posted by the libraries on Facebook is not synchronized with the content they post on Instagram. In most cases $(85 \%$ of the analyzed pages of libraries on social networks) the same information is posted on Facebook as on the website of the library and on Instagram the information on the new acquisitions to the library holding is primarily presented. Content synchronization between library profiles on Facebook, Instagram or Twitter can be observed only on $15 \%$ of the analyzed pages, including the pages of the following libraries:

- Research Library of H.S. Skovoroda Kharkiv National Pedagogical University

Library of the Kryvyi Rih State Pedagogical University

Library of K. D. Ushinsky South Ukrainian National Pedagogical University

Typical information posted on Facebook library accounts is the following: contact details, library news, event announcements, competitions, photo reports of various library events, holiday greetings, the information on the new acquisitions, videos of flash mobs (such as those dedicated to the significant dates or events, e.g. the $150^{\text {th }}$ anniversary of the birth of Lesya Ukrainka), content of virtual exhibitions.

The performance of the libraries on YouTube and the data update rate of the content of their pages opened up on this communication channel, in general, leave a great deal to be desired, because there are profiles where the content has not been updated for years. The total number of YouTube channels of the libraries of pedagogical HEI is 11 channels $(53 \%)$. It is possible to conveniently classify YouTube channels of the libraries of pedagogical HEI into those having:

- High-scale of updateability and representation (content is updated monthly) - such channels are $10 \%$ of the total number of YouTube channels of libraries, i.e. only 1 channel is updated monthly;

- Medium-scale of updateability (content is updated every few months) $-30 \%$, which is 3 library YouTube channels;

- Low-scale of updateability (content is not updated for a year or even 2 years) - $60 \%$, i.e. 6 YouTube channels of libraries. 


\section{AMAZONDA \\ Tovestiga}

YouTube channels of libraries have usually a very small number of subscribers, in contrast to the profiles on Facebook or Instagram.
Figure 3 shows the percentage of YouTube channels of the libraries of pedagogical HEI by the degree of filling with content.

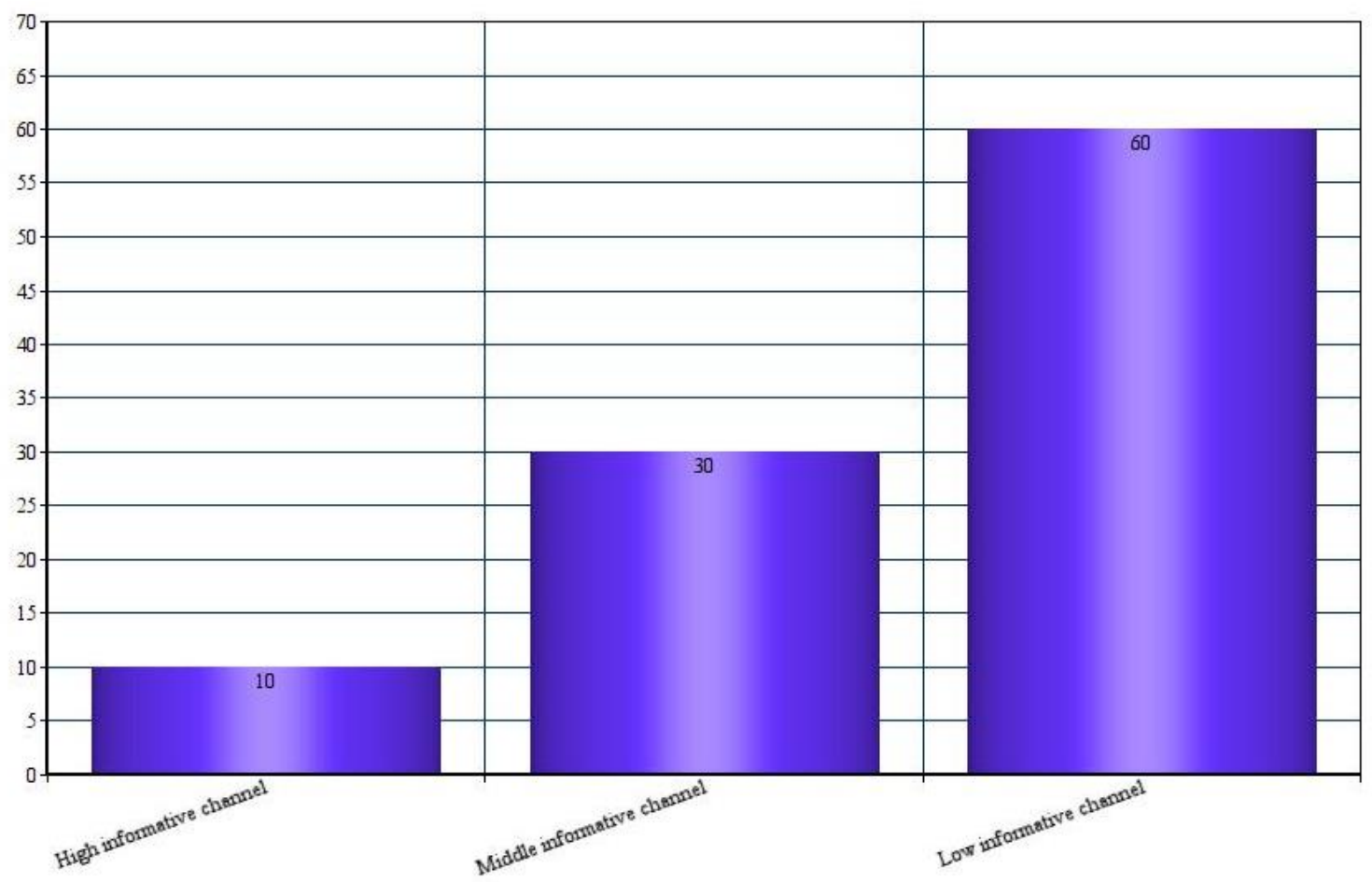

Figure 3. The percentage of YouTube channels of the libraries of pedagogical HEI by the degree of filling with content (by Anna Shelestova)

As for accounts on Twitter, the libraries of pedagogical HEI of Ukraine do not consider this social network popular among youth: only the Twitter profile of the Research Library of the National Pedagogical Drahomanov University is relevant, updated and synchronized with the Facebook page.

According to the results of content analysis of library accounts on the most popular social network Facebook among pedagogical HEI of Ukraine, the rating of official profiles of libraries by the number of subscribers is determined. The five libraries whose accounts have the largest number of subscribers include the following libraries of pedagogical HEI of Ukraine:

- Research Library of the National Pedagogical Drahomanov University - 856 subscribers;

- Research Library of H.S. Skovoroda Kharkiv National Pedagogical University 749 subscribers;

- Library of Drohobych Ivan Franko State Pedagogical University - 546 subscribers;
- Research Library of Ternopil Volodymyr Hnatiuk National Pedagogical University 535 subscribers;

- Library of K. D. Ushinsky South Ukrainian National Pedagogical University - 509 subscribers.

The profiles of the libraries on Facebook are synchronized with the information posted on library websites, duplicating the following website content: news, announcements, recent acquisitions of the library, cultural and educational information, and flash mobs dedicated to significant events, anniversaries of writers and poets, etc.

It is worth pointing out that the vast majority of the content of library accounts of pedagogical HEI are intended to provide information, news or announcements. Messages aimed at zooming in library collections or virtual exhibitions are also posted, and they usually refer the reader to the library website where the content is posted.

Due to the fact that the demographic and age composition of the target audience of users of 
different social media are not the same, libraries should take care of the identity of the content of their official accounts on Facebook and Instagram, in order not to lose the subscribers and to reach as many users as possible by informing about information products and services.

If one compares social networks in terms of the technical capabilities they provide to content publishers, libraries should keep in mind that it is easier to create multimedia content on Facebook, because there are no restrictions on the video duration or the number of characters in the post, as provided on Instagram. It is well known that Instagram has certain restrictions on the size of videos, the number of characters or photos in one post. This aspect may influence the fact that the libraries of pedagogical HEI prefer creating their official accounts on Facebook.

The data update rate of library accounts of pedagogical HEI of Ukraine is high enough in some libraries - even up to several updates per day. Regarding the content: these pages post it not only about the events in the library, but also informative videos, interesting facts related to the socio-cultural life of HEI in general. All this attracts the attention of users and thus increases interest in the library itself. If the librarians' insight of social networking functionality is added to this, it is possible to significantly increase the efficiency of promoting library accounts on them. The main factors influencing the promotion of accounts on the Internet include the following:

- correct use of hashtags (for example, if one constantly uses the same hashtags under posts, Instagram takes them as spam and does not promote the post. Therefore, it is necessary to adjust the use of hashtags on Instagram). It is the hashtags that allow tracking certain topics of the page content. "The use of hashtags also provides identification of the information they denote by Internet search engines, thus expanding the user audience beyond the subscribers of the library page and attracting new readers. As a result, users' search capabilities are greatly expanded, which increases their interest in the library holdings, encourages commenting and reposting the received information and, ultimately, contributes to the comprehensive zooming in and promoting the library holdings" (Tarasenko, 2017, p. 471);

- $\quad$ quality and frequency of content updating. The recommended frequency for updating the content of the library profile is to update it at least four times a week or more often. "At the same time, at least one message, and preferably more, should be aimed at zooming in the library holdings" (Tarasenko, 2017, pp. 471-472);

- posting authenticity. The proper selection of topics for the posting of the library of pedagogical HEI significantly expands its communication capabilities on the social networks. Topics should be designed to generate discussion and encourage active comment by users. Such messages receive quite a lot of comments and likes from readers, and this, in turn, will promote both a specific post and the library profile itself.

\section{Conclusions}

According to the results of the study, it was found that all of the 19 libraries of pedagogical HEI of Ukraine under study have their own websites or web pages and official profiles on popular social media. The main problem that exists today in the work of the library with social networks is the low level of involvement of the target audience, and this, in turn, entails the impossibility of promoting the library and its products / services on the media landscape of the Internet.

Almost $85 \%$ of the surveyed libraries actively use Facebook aiming to self-presentation and promotion of information services through social networking websites, but this network is more popular among middle-aged and elderly people. Libraries do not pay proper attention to those social networks that are more popular among students. To establish quality communication with students and create favourable conditions for their education it is necessary for the libraries of pedagogical HEI to engage in their communication policy such tools that are popular among students and ample opportunities to work with different types of content, including Instagram and YouTube.

It is advisable to develop a single concept of creation and promotion of all websites of the libraries of pedagogical HEI and coordination of their activities in order to implement a common communication strategy for the representation of digital library and information services. The information on social networking functionality and tools for promoting library information products and services should be well structured and accessible to all libraries of the network of pedagogical HEI of Ukraine. It is worth posting on the website of V.O. Sukhomlynskyi State Scientific and Pedagogical Library of Ukraine as 


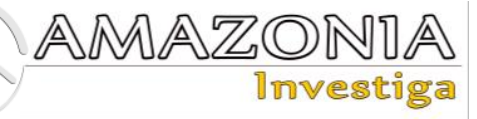

the main methodological centre of the network of educational libraries.

Concerning the content page of the libraries of pedagogical HEI of Ukraine, it must meet the parameters: multi-format, optimal frequency, sufficient content, thematic diversity, interactivity. Thus, to attract and retain their target audience the libraries of pedagogical HEI must comply with the following requirements:

- interesting, reliable, useful and relevant content. Messages posted on official library accounts must be checked for literacy and copyright;

- enabling the users to participate in the library life through discussions, debates, feedback, surveys on social networks;

- coverage of socially important topics that will help maintain and expand communication with the target audience;

- compliance with the optimal volume of the posted messages, i.e. providing a short description with the ability to follow the hyperlink to the full text of the message;

- hashtaging under posts to promote both the post itself and the web page or library account. Properly selected hashtags allow reaching a larger target audience;

- $\quad$ archiving of the content posted on the page;

- prompt response to the users' actions on the page: responses to comments, messages, etc.;

- maximum synchronization of the content of the library pages on different social networks to evenly inform and attract target audiences represented on different social networks;

- cooperation and consolidation with other libraries, relevant institutions, higher education institutions in Ukraine and abroad.

Thus, the basic criterion for the effectiveness of promoting the libraries of pedagogical HEI on social media is the content quality, its authenticity, relevance, social significance, update efficiency, dynamic sharing by the subscribers and steady growth in their number, insight and successful use of functionality of various social networks by librarians.

\section{Bibliographic references}

Bondarenko, V. (2016). Library Internet Service: Current State and Trends. Kyiv: NBUV.

Bulakhova, H. (2016). Advertising Strategy for Promoting Library Products and Services on the Social Network Facebook. Scientific practice of the V.I. Vernadskoho National Library of Ukraine, 43, 331-345.
Bulakhova, H. (2013). Libraries on social networks and a blogosphereas an advertizing medium. Scientific practice of the V.I. Vernadskoho National Library of Ukraine, 36, 192-199.

Bulakhova, H. (2017). Photo Image of the Library in an Interactive Space. Scientific practice of the V.I.Vernadskoho National Library of Ukraine, 46, 313-328.

Davydova, I., Marina, O., Solianyk, A., \& Syerov, Y. (May 2019). Social Networks in Developing the Internet Strategy for Libraries in Ukraine. In Proceedings of the 2019 COAPSN International Workshop on Control, Optimisation and Analytical Processing of Social Networks. COAPSN.

Dobko, T., \& Khemchian, I. (2019). Methodological Principles of Development of Education Libraries as an Important Component of Educational Environment: Results of Scientific Research. Scientific practice of the V.I.Vernadskoho National Library of Ukraine, 56, 90-110.

Horoviy, V. M. (2010). Social information communication, their content and resource: monograph. Kyiv: NBUV.

Hranchak, T., \& Skiter, T. (2019). Internet Marketing in the Activities of Libraries in Ukraine. Ukrainian Journal of Library Science and Information Sciences, 4, 36-55.

Hranchak, T. (2016). Using Social Networks by National Libraries to Present Library Products and Services. Bibliotechnyi visnyk, 1, 18-29.

Humenchuk, A., Michanyn, N., Novalska, T., \& Trach, O. (May 2019). Strategy of the Scientific Educational Libraries of Ukraine Network's Digitalization. In Proceedings of the 2019 COAPSN International Workshop on Control, Optimisation and Analytical Processing of Social Networks. COAPSN.

Kulyk, E. (2015). Virtual Space of the Library as an Environment of Education and Selfeducation for Young People. NBUV Conference. Recovered from http://conference.nbuv.gov.ua/report/view/id 1529

Marina, O. (2012). Libraries and social media: Technology of Interaction. Visnik of the Book Chamber, 8, 1-3.

Marina, O. (2017). Library in Digital Space, Monograph. Kharkiv: KhSAC.

Ministry of Education and Science of Ukraine (2020). Higher education development strategy in Ukraine for 2021-2031. Recovered from: http://www.reform.org.ua/proj_edu_strategy _2021-2031.pdf 
NTB TNTU lleva el nombre de Ivan Pulyuy (2021). Webometrics of repositories of Ukraine Recovered from: https://liblab.tntu.edu.ua/webometric/reposit ories_sites_webometric_table.html

Pasmor, N., \& Frolova, N. (October 2016). Web Site and Social Networks as a Means of Internet Representation of the University Library. In Proceedings of the 2016 Korolenko Readings. Libraries, Archives, Museums: Innovative Models of Development.

Peleshchyshyn O., Molodetska, K., Solianyk, A., \& Kravets, R. (November 2019). Modelling the Complex of Automation of Company Marketing Activity in Online Communities. In Proceedings of the 2019 International Workshop on Conflict Management in Global Information Networks co-located with 1st International Conference on Cyber Hygiene and Conflict Management in Global Information Networks. CMiGIN. CyberConf.
Samsonov, M. (2012). Advertising of Libraries on Online Social Networks. Scientific practice of the V.I.Vernadskoho National Library of Ukraine, 33, 532-542.

Strunhar, V. (2014). Library and social media: Terminological and Conceptual Aspect. Bibliotechnyi visnyk, 6, 23-27.

Strunhar, V. (2016). Methodology of research of content of library pages in social media. Scientific practice of the V.I.Vernadskoho National Library of Ukraine, 43, 488-500.

Strunhar, V. (2017). Representing a Library in an Interactive Media Environment: Content Analysis. Scientific practice of the V.I. Vernadskoho National Library of Ukraine, 46, 329-344.

Tarasenko, N. (2017). Information Communications on the Social Networks: Standardization Aspects of the Library Segment. Scientific practice of the V.I. Vernadskoho National Library of Ukraine, 46, 455-477. 